\title{
Rhizobacteria Associated with Spilanthes acmella Murr. Confer Drought-Tolerance and Plant Growth Promotion
}

\author{
Menaka Thakur ${ }^{1, \dagger} \mathbb{( D}$, Divya Mittal ${ }^{2, \uparrow} \mathbb{D}^{\mathbb{D}}$, Prem Kumar Khosla ${ }^{1 \mathbb{D}}$, Vipin Saini ${ }^{3}{ }^{\mathbb{D}}$, \\ Reena V. Saini ${ }^{2, *}$ (D) , Adesh K. Saini 1,2,* (D)
}

1 School of Biological and Environmental Sciences, Faculty of Sciences, Shoolini University of Biotechnology and Management Sciences, Bajhol, Solan, 173229, Himachal Pradesh, India; vc@shooliniuniversity.com (P.K.K.); menakathakur89@gmail.com (M.T.);

2 Department of Biotechnology, MMEC, Maharishi Markandeshwar (Deemed to be University), Mullana, Haryana, 133207, India; sainiade@gmail.com (A.K.S.); reenavohra10@gmail.com (R.V.S); diyamittal.ms@gmail.com (D.M.);

3 Department of Pharmacy, Maharishi Markandeshwar University, Kumarhatti, Solan, Himachal Pradesh, 173229, India; vipinsaini31@ rediffmail.com (V.S.);

$\dagger \quad$ the authors equally contributed to this work and shared the first position;

* Correspondence: sainiade@gmail.com (A.K.S.); reenavohra10@gmail.com (R.V.S.);

Received: 5.01.2021; Revised: 30.01.2021; Accepted: 2.02.2021; Published: 7.02.2021

\begin{abstract}
Plant growth-promoting rhizobacteria (PGPR) exhibit biocontrol and biofertilzer traits and help plants survive adverse environmental conditions. In this study, the rhizobacteria are explored for their ability to tolerate drought stress and their potential to act as plant growth promoters. Herein, we have isolated bacterial strains from the rhizosphere of Spilanthes acmella Murr. (toothache plant) found in the Shivalik hills region of Himachal Pradesh. We screened nine drought-tolerant culturable bacteria by analyzing their ability to survive in varying concentrations of polyethylene glycol (PEG) $(10 \%$ $50 \%$ ), which is further supported by their 1-aminocyclopropane-1-carboxylic acid (ACC) deaminase activity and their ability to release exopolysaccharides (EPS). Strains having these activities are identified by $16 \mathrm{~S}$ rDNA analysis, which reveals that they belong to four different bacteria genera, namely Klebsiella, Enterobacter, Burkholderia, and Pantoea. These isolates also harbor plant growthpromoting traits such as solubilization of phosphate, production of indole-3-acetic acid (IAA), siderophore, ammonia, hydrogen cyanide $(\mathrm{HCN})$, and antifungal activity. The Enterobacter cloacae showed maximum drought tolerance among all the other isolates. We found that the drought stress of 60\% PEG inhibited wheat seedlings' growth, but the bacterization with the isolated strains stimulated seedling growth. Hence we conclude that these drought-tolerant PGPR from the rhizosphere of $S$. acmella Murr. can be utilized to enhance the survival and growth of plants under drought stress. The isolated strains not only exhibit the drought-tolerant ability but also show the biocontrol and biofertilizer traits. Inoculation of these strains could help the plant survive under adverse environmental conditions.
\end{abstract}

Keywords: Spilanthes acmella Murr.; Shivalik hills; drought stress; phosphate solubilization; siderophore; bacterization.

(C) 2021 by the authors. This article is an open-access article distributed under the terms and conditions of the Creative Commons Attribution (CC BY) license (https://creativecommons.org/licenses/by/4.0/).

\section{Introduction}

Drought stress is a serious agricultural problem that reduces crop productivity [1]. By 2050, more than $50 \%$ of the earth's cultivable land will get affected by drought, leading to a severe decrease in agricultural production. Moreover, the world's population is assumed to reach 9 billion by 2050, so it is necessary to increase crop production to encourage food security 
[2]. Therefore, there is a dire need to find solutions to abate the consequences of drought on agriculture productivity [3].

Several mechanisms can be employed to mitigate the drought stress like morphological alterations, tuning of osmolites, augmentation of diverse water resources, modification of antioxidant defense systems to reduce reactive oxygen species (ROS) related changes and, reorientation of stress-related genes [4]. Other methods include improving the breed of plants either by traditional methods or by transgenic approach and developing new irrigation techniques. Unfortunately, these methods are highly labor-intensive and challenging to be applied under field conditions [5].

Plants symbiotically harbor microbes that could either be endophytes or rhizosphere associated. Using those plant growth-promoting rhizobacteria (PGPR) that benefit the plant to grow under low water conditions could be a possible solution. PGPR is associated with plant roots, and they either directly or indirectly help to enhance the growth of plants [6]. The PGPR's mechanisms to enhance plant growth include phytohormones, nitrogen fixation, phosphates solubilization, and siderophore production for quenching iron, and ACC (1aminocyclopropane-1-carboxylic acid) deaminase production. ACC is the precursor of ethylene [7]. It was reported that PGPR strains (Bacillus sp. and Pseudomonas sp.) produce the enzyme ACC deaminase that catabolizes ACC to NH4, and $\alpha$-ketobutyrate reduces the level of ethylene synthesis and damage induced by ethylene to plant [8].

Under drought stress condition bacteria like Pseudomonas produces exopolysaccharide (EPS) which protects bacteria from drought by enhancing water retention capacity and regulating the diffusion of organic carbon sources [9]. Due to the EPS, these bacteria get attached and colonize the plant roots with the help of fibrillar material that permanently connects the bacteria to the root surface [10]. It has been shown that PGPR help in alleviating the effects of drought [11-13].

One way to identify and isolate drought-resistant PGPR is to find them from plants that face drought-like Spilanthes acmella Murr., which is a threatened medicinal plant. It is an annual herb, found throughout India, ascending to $5000 \mathrm{ft}$., in all warm regions [14], including lower Shivalik Hills of Himachal Pradesh [15-16]. It is utilized for various medicinal usages [17-18]. No reports are available on the stress-tolerant plant growth-promoting rhizospheric bacteria isolated from $S$. acmella Murr. Therefore, the present study was aimed at isolating stress-tolerant PGPR from the rhizosphere of S. acmella Murr. with multiple plant-growthpromoting and antagonistic activities against plant fungal pathogens. However, the stresstolerant activity of rhizobacteria in other plants was reported earlier [19-21].

Herein, we isolated rhizospheric bacteria from $S$. acmella Murr., which can grow under in vitro drought conditions and harbored plant growth-promoting traits. We carried out seedling based bacterization experiments, which strongly implicate that these microbes could improve growth under water deficiency stress.

\section{Materials and Methods}

\subsection{Isolation of root-associated phosphate solubilizing bacteria.}

From the rhizosphere of $S$. acmella Murr., the soil samples were collected randomly from four districts (Hamirpur, Bilaspur, Mandi, and Solan) of Himachal Pradesh. A total of 36 rhizospheric soil samples were collected. For isolation of bacteria, $1 \mathrm{~g}$ of rhizospheric soil was dissolved in $9 \mathrm{ml}$ sterilized distilled water and incubated on an incubator shaker at the speed of 
$250 \mathrm{rpm}$ at $37^{\circ} \mathrm{C}$ for $30 \mathrm{~min}$, and later the soil was settled by centrifugation at $685 \times \mathrm{g}$ for $5 \mathrm{~min}$. The supernatant was collected and centrifuged at $5590 \times \mathrm{g}$ for $10 \mathrm{~min}$ to settle all the microbes. The resultant pellet was dissolved in $500 \mu \mathrm{l}$ of $30 \%$ glycerol and preserved at $-80^{\circ} \mathrm{C}$. Using the serial dilution method, the number of bacteria per $\mathrm{g}$ of soil was enumerated. The culturable bacterial strains were further characterized as described earlier [22]. Around 100-150 bacterial colonies were observed on nutrient agar medium (NAM). Then the colonies were picked, and patching was done on Pikovskaya's agar media (PAM) to identify strains showing clear halo zone on PAM. Then the bacterial strains were selected and analyzed for colony morphology, Gram-positive or Gram-negative reaction, catalase, and oxidase reactions as described earlier [22]. Catalase activity of strains was analyzed by forming oxygen bubbles with $3 \%$ hydrogen peroxide solution, whereas oxidase activity was analyzed by the oxidation of TMPD (tetramethyl-p phenylenediamine dihydrochloride).

\subsection{Screening of bacterial isolates for drought tolerance.}

Previously, it was shown that PEG induced osmotic stress by reducing the water potential of plant cells [23]. Thus, PEG could be used to identify bacteria that were tolerant to drought. The trypticase soy broth (TSB) with varying water potentials (10\% PEG for -0.15 $\mathrm{MPa}, 20 \%$ PEG for $-0.49 \mathrm{MPa}, 30 \%$ PEG for $-1.03 \mathrm{MPa}, 40 \%$ PEG for $-1.76 \mathrm{MPa}$ and $50 \%$ PEG for -2.7 MPa) were made carrying the appropriate concentrations of PEG-6000 [24,12]. Overnight grown above-mentioned bacterial strains were inoculated in $10 \mathrm{ml}$ TSB with different PEG concentrations and grown at $28^{\circ} \mathrm{C}$ for $24 \mathrm{~h}(120 \mathrm{rpm})$. Growth was assessed by measuring absorbance at OD $600 \mathrm{~nm}$.

\subsection{Molecular characterization.}

For the genetic characterization of bacteria, 16S rDNA sequencing was performed as described earlier by [25,26]. DNA extraction and purification were done by Quick-DNA Fungal/bacterial Miniprep Kit (Zymo Research, India). By using universal primers 27F (5'AGA GTT TGA TCC TGG CTC AG-3') and 1492R (5'GGT TAC CTT GTT ACG ACT T$3^{\prime}$ ), the 16S rDNA gene was amplified and, purification of amplicons was done by using QIAquik Gel extraction kit (Qiagen, India). After DNA sequencing of amplicons, the results were compared against GenBank database using the basic local alignment search tools (BLAST). The sequence of respective strains was deposited in the National Centre for Biotechnology Information (NCBI) database (http://www.ncbi.nlm.nih.gov/BLAST). The sequences thus obtained were submitted to the GenBank for their accession numbers. The evolutionary relationship of sequences was determined. The Phylogenetic tree was made using maximum likelihood from PhyML integrated into Unipro UGENE.

\subsection{Effects of isolated strains on seed germination under drought stress.}

The potential drought-tolerant bacterial strains isolated from the rhizosphere of $S$. acmella Murr. were analyzed on Triticum aestivum L. (commonly known as wheat) for their competence to exhibit the plant growth promotion under drought stress. A batch of 50 seeds was surface sterilized with $70 \%$ ethanol for $1 \mathrm{~min}$ and then in sodium hypochlorite for $3 \mathrm{~min}$, followed by washing with $70 \%$ ethanol for $30 \mathrm{~s}$ and finally, washing thrice with autoclaved distilled water for $10 \mathrm{~min}$ as described earlier [25]. To analyse the surface sterilization, the last wash was plated on NAM and incubated at $37^{\circ} \mathrm{C}$ for $72 \mathrm{~h}$. Bacterial inoculum was prepared by 
inoculating the bacterial strains in $50 \mathrm{ml}$ nutrient broth media incubated at $37^{\circ} \mathrm{C}$ until the $\mathrm{OD}_{600}$ reached 0.1 . Then, the surface-sterilized seeds were soaked in $50 \mathrm{ml}$ bacterial culture for $4 \mathrm{~h}$ followed by treatment with $60 \%$ PEG solution and kept at $30^{\circ} \mathrm{C}$ in Petri plates with moist paper for 12 days in BOD incubator. Later the seedlings were analyzed for growth of root and shoot length [27]. Seeds without PEG and with 60\% PEG were taken as control.

\subsection{Determination of plant growth-promoting traits of the isolates.}

The bacterial strains were further analyzed for in vitro PGP properties like production of Indol acetic acid (IAA), hydrogen cyanide ( $\mathrm{HCN})$, ammonia and, siderophore as described earlier [25]. IAA production in PGPR is a very fruitful activity of this group [28-29]. Its production and quantification by phosphate solubilizing bacterial strains were carried out by using the Salkowski assay. For this, the bacterial strains were incubated in $2 \mathrm{ml}$ of LB (LuriaBertani) broth supplemented with L-tryptophan $\left(200 \mu \mathrm{g} \mathrm{ml}^{-1}\right)$ and without L-tryptophan at $30^{\circ} \mathrm{C}$ in the dark with shaking at $250 \mathrm{rpm}$ for $48 \mathrm{~h}$. After $48 \mathrm{~h}$, the culture was centrifuged at $6,000 \times \mathrm{g}$ for $10 \mathrm{~min}$, and supernatants were obtained. $500 \mu \mathrm{l}$ of supernatant was mixed with $500 \mu \mathrm{l}$ of Salkowski's reagent $\mathrm{R} 1\left(\mathrm{FeCl}_{3}, 12 \mathrm{gl}^{-1}\right.$ in $\left.42.9 \% \mathrm{v} / \mathrm{v} \mathrm{H}_{2} \mathrm{SO}_{4}\right)$ and after $20 \mathrm{~min}$ incubation in the dark, the absorbance at $535 \mathrm{~nm}$ was determined. The concentration of IAA was determined by standard curves using purified IAA.

The bacterial strains were also analyzed for their ability to produce hydrogen cyanide (HCN) [25]. For this, streaking of bacterial strains was done on modified NAM supplemented with glycine $\left(4.4 \mathrm{gl}^{-1}\right)$. A Whatman filter paper number 1 soaked with $\mathrm{Na}_{2} \mathrm{CO}_{3}(2 \%)$ in picric acid solution $(0.5 \%)$ was placed inside the plate's lid so that it covered the NAM without touching the top surface of the growing strains. Parafilm sealed plates were incubated at $30^{\circ} \mathrm{C}$ for 4 days. The development of orange to red color on Whatman filter-paper indicated the production of HCN by bacterial strains.

We also tested the isolated PSB for their ability to produce ammonia. For this, the bacterial strains were cultured in $10 \mathrm{ml}$ peptone water (peptone $10 \mathrm{gl}^{-1} \mathrm{in}^{\mathrm{gg}}{ }^{-1} \mathrm{NaCl}$ ) at $30{ }^{\circ} \mathrm{C}$ for $72 \mathrm{~h}$. Later on, the addition of $0.5 \mathrm{ml}$ Nessler's reagent was done to the culture, and the color change was observed. The transformation of brown to the yellow color indicated the ammonia production by the bacterial strains [25].

The siderophores production by bacterial strains were analyzed by observing the ability of the strains to produce an orange halo zone on Chrome azurol S agar (CAS-agar) media (0.33 $\mathrm{mM}$ Chrome azurol $\mathrm{S}$ dye, $2.47 \mathrm{mM} \mathrm{FeCl}_{3} .6 \mathrm{H}_{2} \mathrm{O}, 0.36 \mathrm{mM} \mathrm{N}, \mathrm{N}, \mathrm{N}, \mathrm{N}-\mathrm{Cetyl}$ trimethyl ammonium bromide, $0.33 \mathrm{mM} \mathrm{HCl}, 42.23 \mathrm{gl}^{-1} \mathrm{King}^{\mathrm{s}} \mathrm{B}$ base) as described previously [25]. For this, the bacterial strains were inoculated in $5 \mathrm{ml}$ nutrient broth media and incubated at $30^{\circ} \mathrm{C}$ for $24 \mathrm{~h}$. Then, $2 \mu \mathrm{l}$ of bacterial culture was spotted on CAS-agar media, incubated at $30^{\circ} \mathrm{C}$, and observed for orange halos forming around the spotted bacterial culture. The size of the halos was measured by subtracting the colony diameter from the total diameter.

The antagonistic activity against phytopathogenic fungi (Rosellinia sp. and Fusarium sp.) was also determined as described earlier [25,30]. The Fusarium sp. (ITCC: 6903) was obtained from India type culture collection (India Agriculture Research Institute), and Rosellinia sp. (HG964402) was obtained from the Department of Biotechnology, Shoolini University, Solan. These fungi were grown on potato dextrose agar (PDA) medium, and later a fungal disc (4 mm radius) was excised and placed on another PDA media. Bacterial strains were streaked on both sides of the fungal disc at a distance of $2 \mathrm{~cm}$ away from the fungal disc and incubated at $25^{\circ} \mathrm{C}$. The percentage zone of inhibition was calculated by $(\mathrm{C}-\mathrm{T}) / \mathrm{Cx} 100$, 
where " $\mathrm{C} "$ is the average diameter of fungal growth in the control and " $\mathrm{T}$ " is the average diameter of fungal growth in the treatment.

\subsection{Screening for ACC deaminase activity.}

The drought-tolerant bacterial isolates were screened for ACC deaminase activity on Dworkin and Foster (DF) salt minimal medium with ACC as sole nitrogen source [31]. All the isolates were cultured in $5 \mathrm{ml}$ of TSB for $24 \mathrm{~h}$ with shaking $(120 \mathrm{rpm})$ at $28{ }^{\circ} \mathrm{C}$. The cultures were centrifuged at 3,000 g for $5 \mathrm{~min}$. The pellet was washed twice with sterile $0.1 \mathrm{M}$ Tris$\mathrm{HCl}(\mathrm{pH} 7.5)$, resuspended in $1 \mathrm{ml}$ of $0.1 \mathrm{M}$ Tris- $\mathrm{HCl}(\mathrm{pH} 7.5)$, and spot inoculated on Petri plates containing modified DF minimal salts medium $\left[\mathrm{KH}_{2} \mathrm{PO}_{4}, 4.0 \mathrm{~g}\right.$; $\mathrm{Na}_{2} \mathrm{HPO}_{4}, 6.0 \mathrm{~g} ; \mathrm{MgSO}_{4}$ $.7 \mathrm{H}_{2} \mathrm{O}, 0.2 \mathrm{~g}$; micro-nutrient solution $\left(\mathrm{FeSO}_{4} .7 \mathrm{H}_{2} \mathrm{O}, 1 \mathrm{mg} ; \mathrm{H}_{3} \mathrm{BO}_{3}, 10 \mu \mathrm{g} ; \mathrm{ZnSO}_{4} .7 \mathrm{H}_{2} \mathrm{O}, 70 \mu \mathrm{g}\right.$; $\mathrm{Na}_{2} \mathrm{MoO}_{4}, 10 \mu \mathrm{g} ; \mathrm{MnCl}_{2}, 10 \mu \mathrm{g} ; \mathrm{CuSO}_{4} 50 \mu \mathrm{g}$; in distilled water, 1,000 ml] supplemented with $3 \mathrm{mM}$ ACC as the sole nitrogen source. Plates with $\left(\mathrm{NH}_{4}\right)_{2} \mathrm{SO}_{4}(0.2 \% \mathrm{w} / \mathrm{v})$ were used as the positive control, and with only DF minimal salts medium without ACC were used as the negative control. The plates were incubated at $28^{\circ} \mathrm{C}$ for 3 days. The growth of bacterial isolates on ACC-supplemented plates was compared with the negative and positive controls. The bacterial strains which were able to deaminase ACC were selected based on their growth by utilizing ACC.

\subsection{Extraction and purification of exopolysaccharides (EPS).}

The bacterial strains that showed growth in media having $20 \%$ PEG were analyzed for EPS production under normal and stressed conditions according to the method given by [9]. EPS was extracted from bacterial cultures grown for $72 \mathrm{~h}$ in TSB $(20 \%$ PEG 6000 was added to TSB for inducing the stress). Before centrifugation, highly viscous bacterial cultures were diluted by adding $0.85 \% \mathrm{KCl}$. After that, the bacterial cultures were centrifuged $(20,000 \mathrm{~g}, 25$ min) and the supernatant was separated. For complete extraction of the EPS the pellet was washed twice with $0.85 \% \mathrm{KCl}$. The extraction of intracellular polysaccharides was done by testing for the presence of DNA in the supernatant by diphenylamine (DPA) reagent [9]. Protein concentration was estimated by Bradford's reagent. The filtration of supernatant was done through $0.45 \mu \mathrm{m}$ syringe filters and dialyzed against water for $18 \mathrm{~h}$ at $4^{\circ} \mathrm{C}$. The dialysate was centrifuged $(20,000 \mathrm{~g})$ for $25 \mathrm{~min}$ and mixed with 3 volumes of absolute ice-cold ethanol and kept overnight at $4^{\circ} \mathrm{C}$ and then centrifuged (10,000 g, $\left.15 \mathrm{~min}\right)$. The precipitated EPS was suspended in water and again dialyzed against water and precipitated as described above. Total carbohydrate content in the precipitated EPS was determined as described earlier [9]. The EPS solution $(0.5 \mathrm{ml})$ and the phenol solution $(0.1 \mathrm{ml})$ were added to the centrifuge tube and were vortexed. Then $0.5 \mathrm{ml}$ of concentrated $\mathrm{H}_{2} \mathrm{SO}_{4}$ was added gently along the side of the tube. The tubes were then vortex stirred for $5 \mathrm{~s}$ and incubated at $22^{\circ} \mathrm{C}$ for $30 \mathrm{~min}$. followed by cooling down to room temperature and measuring absorbance at $490 \mathrm{~nm}$ using distilled water as blank.

\subsection{Statistical analysis.}

Statistical analysis was done by using Microsoft office excel 2013. One-way ANOVA and Tukey's multiple comparison test and Two-way ANOVA and Bonferroni post-tests were used to check the data's significance level. Analysis of the data was carried out using Graphpad Prism version 5.02 with a completely randomized analysis of variance $(p<0.05)$.. 


\section{Results and Discussion}

\subsection{Isolation of culturable bacteria exhibiting phosphate solubilization.}

Total 36 rhizospheric soil samples collected from the rhizosphere of S. acmella Murr. from Shivalik hills of Himachal Pradesh were serially diluted and plated on NAM plates. After $24 \mathrm{~h}$ of incubation at $37^{\circ} \mathrm{C}$, the $\mathrm{CFU} \mathrm{g}{ }^{-1}$ of soil was $\sim 1 \times 10^{8} \mathrm{CFU} \mathrm{g}^{-1}$ on NAM. About $100-150$ colonies from each NAM plate were picked and analyzed for phosphate solubilization by using PAM at $30^{\circ} \mathrm{C}$ for $48 \mathrm{~h}$. After incubation, we found a total of $53 \mathrm{PSB}$, which exhibited a clear halo zone. The representative PSB colonies were purified and preserved for further studies. We found that all culturable PSB were Gram-negative, oxidase negative, and catalase-positive.

\subsection{Screening of isolates for drought tolerance.}

Fifty-three PSB isolates from rhizospheric soil of $S$. acmella Murr. were further screened for drought tolerance by analyzing their competence to grow in varying levels of polyethylene glycol 6,000 (PEG 6,000) as described in materials and methods. Out of the 53 isolates, only 9 were able to grow in the presence of PEG (an induced stress condition). These isolates showed different levels of stress tolerance ability. We found a decline in optical density as PEG concentration was increased from 10 to 50\% PEG. The highest drought tolerance activity was exhibited by isolate Pa3S3C (50\% PEG), Pa2S2E (50\% PEG), C3S3P (50\% PEG), Pa2S2C (50\% PEG), C3S3F (50\% PEG) followed by H3S3A (40\% PEG), C3S3D (30\% PEG), C3S3G (30\% PEG), C3S3E (20\% PEG). The results were analyzed by two-way ANOVA analysis followed by Bonferroni post-tests (Figure 1). The survival rate of bacterial strains was also examined. The growth in control having no PEG is taken as 100\%, and growth with PEG supplement was calculated with respect to control. We found that strain C3S3G showed maximum survival percentage at $10 \%$ PEG concentration compared to other strains, but by the increase in PEG concentration, it could not persist its growth and perish away at $40 \%$ PEG concentration.

Control (without PEG)
$10 \%$ PEG
$20 \%$ PEG
$30 \%$ PEG
미묘 $40 \%$ PEG
$50 \%$ PEG

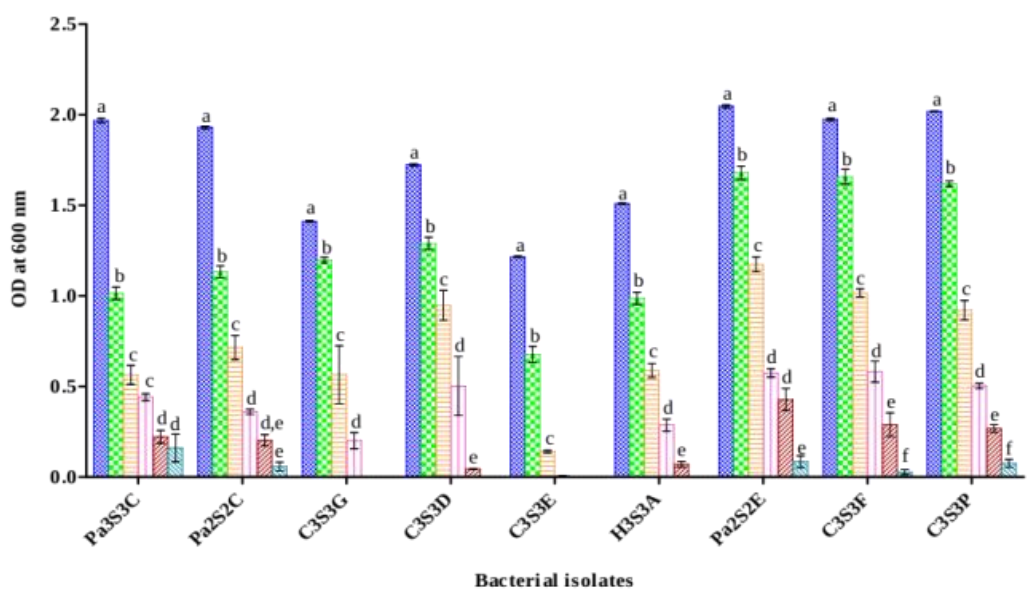

Figure 1. Growth of nine rhizobacteria under non-stressed (control) and drought-stressed conditions of different PEG concentrations. All the treatments show statistically significant differences in growth under different PEG concentrations compared to control (without PEG) at $p \leq 0.05$ (Bonferroni test). Columns with a similar letter show non-significant results and with different letters show significant results. 
Table 1. Plant growth-promoting activities of drought-tolerant bacterial isolates from rhizosphere of Spilanthes acmella Murr.
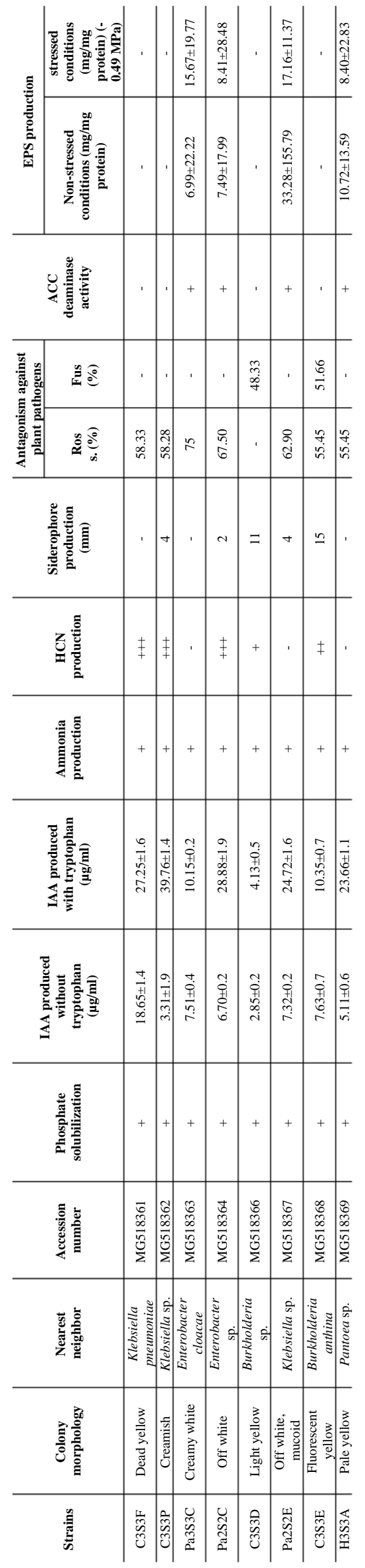


\subsection{Molecular characterization.}

We further went on to identify the bacterial strains using $16 \mathrm{~S}$ rDNA analysis. The DNA was isolated and 16S rDNA gene was amplified by PCR. Amplicons were found to be $\sim 1400$ bp and were identified by sequencing. The sequences thus obtained were submitted to the GenBank (Table 1). After BLAST analysis, the 16S rDNA gene sequence of the strains showed maximum similarity with the closest-type strains, as shown in Table 1. It was found that the rhizobacteria isolated in the present study were Klebsiella pneumonia (MG518361), Klebsiella sp. (MG518362), Enterobacter cloacae (MG518363), Enterobacter sp. (MG518364), Burkholderia anthina (MG518365), Burkholderia sp. (MG518366), Klebsiella sp. (MG518367), Burkholderia anthina (MG518368), Pantoea sp. (MG518369) (Table 1).

The phylogenetic tree was constructed by using maximum likelihood from PhyML integrated into Unipro UGENE. This analysis involved nucleotide sequences of nine strains indicating an evolutionary relationship between them (Figure. 2). Bacterial strain Klebsiella sp. C3S3P and Klebsiella sp. Pa2S2E shared the same gene pool and were closely related to each other. They also clustered with Klebsiella sp. C3S3F. Similarly, Enterobacter sp. Pa2S2C and Enterobacter sp. Pa3S3C shared the same gene pool and were closely related to each other. Burkholderia sp. C3S3G and Burkholderia C3S3E were also closely related to each other and also clustered with Burkholderia sp. C3S3D.

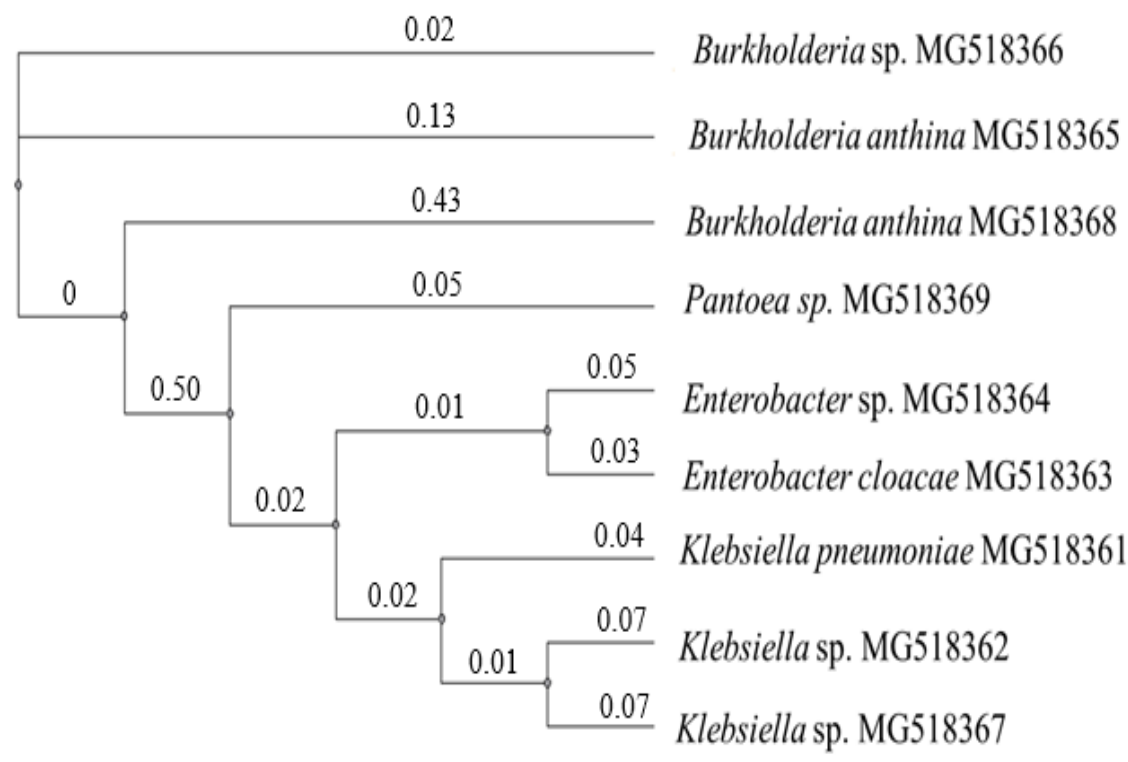

Figure 2. Phylogenetic analysis of bacteria isolated from the rhizospheric soil of Spilanthes acmella Murr. The name of the genera is followed by the accession number as indicated in Table 1. Distance is shown with numerals.

\subsection{Under drought stress, the isolated strains improved seed germination.}

We found that the germination of wheat seedlings (Triticum aestivum L.) was reduced under 60\% PEG compared to without PEG (control). We have also observed that isolated strains were able to grow under drought stress. So we further analyzed the growth of seedlings in PEG 6000 to confirm either isolated strains make them able to grow or not. After 12 days of incubation at $30^{\circ} \mathrm{C}$, the different plant growth criteria like shoot-length, root-length, number of roots, and number of leaves were analyzed (Figure. 3). We found a significant rise in shootlength and root-length of wheat seedlings incubated with different bacteria compared to control 
seedlings (treated with 60\% PEG). A maximum of 1.28-fold rise in shoot length was found in the seedlings treated with H3S3A bacteria (Pantoea sp.). Similarly, the root length was increased by $\sim 1.23$ to 2.8 -fold compared to control. Around 2.8-fold rise in the root, the length was found in seedlings treated with $\mathrm{C} 3 \mathrm{~S} 3 \mathrm{E}$ strain (Burkholderia sp.) and a minimum 1.23 fold increase in the case of Pa2S2E bacteria (Klebsiella sp.). The root and shoot length data were analyzed by one-way analysis of variance (ANOVA) and Tukey's multiple comparison test (Table 2). In the case of root length, it showed a significant difference between all the treatments and control except PEG + Klebsiella sp. vs. PEG + Burkholderia sp., PEG + Enterobacter sp. Vs. PEG + Burkholderia anthina. Similarly, in the case of shoot length, a significant difference was found between all the treatments and control except PEG vs. PEG + Klebsiella sp. and PEG + Enterobacter sp. vs PEG + Burkholderia sp. We further found that the seedlings induced drought-stressed treated with the isolated bacterial strains showed higher shoot length and root length in comparison to the untreated seedlings, which were only treated with 60\% PEG (Table 2).

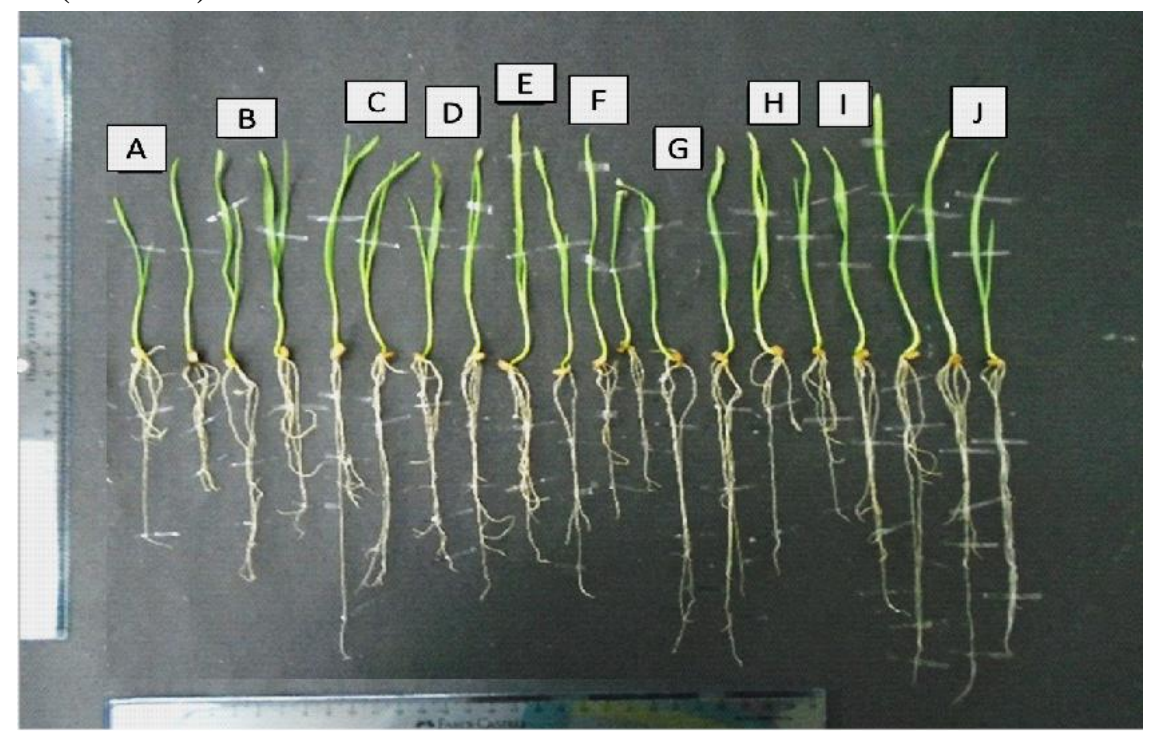

Figure 3. Wheat seedling treated with different bacteria and $60 \%$ PEG followed by distilled water. (A) Only PEG, (B) PEG+ Klebsiella sp., (C) PEG+ Enterobacter sp., (D) PEG+ Klebsiella pneumoniae, (E) PEG+ Enterobacter cloacae, (F) PEG+ Klebsiella sp., (G) PEG+ Burkholderia anthina, (H) PEG+ Burkholderia sp., (I) PEG+ Pantoea sp., (J) PEG+Burkholderia anthina.

Table 2. Effect of bacterial inoculation on induced drought-stressed wheat seedlings. All the treatments show a statistically significant difference in root length and shoot length compared to control seedlings at $p \leq 0.05$ (Tukey's test). Values with different letters are significantly different, and with the same letters are nonsignificant.

\begin{tabular}{l|l|l|l|l|l} 
Treatment & Shoot length $(\mathbf{c m})$ & Root length $(\mathbf{c m})$ & Seedling length $(\mathbf{c m})$ & $\begin{array}{l}\text { No. } \\
\text { roots }\end{array}$ & $\begin{array}{l}\text { No. of } \\
\text { leaves }\end{array}$ \\
\hline Only PEG & $10.5 \pm 0.05^{\mathrm{a}}$ & $6.5 \pm 0.08^{\mathrm{a}}$ & $17.03 \pm 0.14$ & 5 & 2 \\
\hline PEG + Klebsiella sp. & $11 \pm 0.06^{\mathrm{b}}$ & $11.5 \pm 0.03^{\mathrm{b}}$ & $22.53 \pm 0.08$ & 4 & 2 \\
\hline PEG + Enterobacter sp. & $11.6 \pm 0.03^{\mathrm{c}}$ & $16 \pm 0.08^{\mathrm{c}}$ & $27.66 \pm 0.12$ & 4 & 2 \\
\hline PEG + Klebsiella pneumoniae & $10.6 \pm 0.03^{\mathrm{a}}$ & $11.2 \pm 0.08^{\mathrm{b}}$ & $21.63 \pm 0.12$ & 5 & 2 \\
\hline PEG + Enterobacter cloacae & $13 \pm 0.11^{\mathrm{e}}$ & $10.5 \pm 0.03^{\mathrm{e}}$ & $23.73 \pm 0.12$ & 5 & 2 \\
\hline PEG + Klebsiella sp. & $12 \pm 0.05^{\mathrm{f}}$ & $8 \pm 0.06^{\mathrm{f}}$ & $20.06 \pm 0.12$ & 4 & 2 \\
\hline PEG + Burkholderia anthina & $11.3 \pm 0.03^{\mathrm{g}}$ & $15.8 \pm 0.03^{\mathrm{c}}$ & $27.16 \pm 0.06$ & 5 & 2 \\
\hline PEG + Burkholderia sp. & $11.7 \pm 0.05^{\mathrm{c}}$ & $11.6 \pm 0.08^{\mathrm{b}}$ & $23.23 \pm 0.03$ & 4 & 2 \\
\hline PEG + Pantoea sp. & $13.5 \pm 0.08^{\mathrm{i}}$ & $17.5 \pm 0.03^{\mathrm{i}}$ & $31.06 \pm 0.12$ & 5 & 2 \\
\hline PEG + Burkholderia anthina & $12.7 \pm 0.03^{\mathrm{j}}$ & $18.2 \pm 0.03^{\mathrm{j}}$ & $30.96 \pm 0.03$ & 5 & 2
\end{tabular}




\subsection{Characterization of isolated rhizobacteria for plant growth-promoting traits.}

Rhizospheric bacteria have been shown to exhibit plant growth-promoting traits like biofertilizer and biocontrol. Therefore, we tested the biofertilizer and biocontrol of the phosphate solubilizing bacterial strains present in the rhizosphere of S. acmella Murr. towards plant growth. We analysed the nine isolated strains for exhibiting production of IAA, siderophore, HCN and, antifungal activity against Fusarium sp. and Rosellinia sp. The production of IAA was observed with or without supplemented with tryptophan. The bacterial strains showed a low amount of IAA production without amendment of tryptophan, whereas after the amendment of $200 \mu \mathrm{g} / \mathrm{ml}$ tryptophan to the nutrient broth, it enhances IAA production. It was observed that the color intensity increased as the concentration of IAA increased in the supernatant. With addition of tryptophan maximum IAA production was shown by $\mathrm{C} 3 \mathrm{~S} 3 \mathrm{P}$ strain $(\sim 39.76 \mu \mathrm{g} / \mathrm{ml})$, followed by Pa2S2C $(\sim 28.88 \mu \mathrm{g} / \mathrm{ml}), \mathrm{C} 3 \mathrm{~S} 3 \mathrm{~F}(\sim 27.25 \mu \mathrm{g} / \mathrm{ml}), \mathrm{Pa} 2 \mathrm{~S} 2 \mathrm{E}$ $(\sim 24.72 \mu \mathrm{g} / \mathrm{ml}), \mathrm{H} 3 \mathrm{~S} 3 \mathrm{~A}(\sim 23.66 \mu \mathrm{g} / \mathrm{ml}), \mathrm{C} 3 \mathrm{~S} 3 \mathrm{E}(\sim 10.35 \mu \mathrm{g} / \mathrm{ml})$, Pa3S3C $(\sim 10.15 \mu \mathrm{g} / \mathrm{ml})$, C3S3G $(\sim 6.8 \mu \mathrm{g} / \mathrm{ml})$, and C3S3D $(\sim 4.13 \mu \mathrm{g} / \mathrm{ml})$ (Table 1).

All the isolated strains were positive for ammonia production. They show deep brown to yellow color appearance after the addition of Nessler's reagent. Production of HCN by PGPR is linked to biocontrol trait. We found that C3S3F, C3S3P, Pa2S2C, C3S3G, C3S3D, C3S3E showed orange color on the filter paper carrying picric acid solution indicating their ability to produce HCN whereas, Pa3S3C, Pa2S2E, H3S3A did not show any color change (Table 1).

Furthermore, we tested for siderophore release by bacterial strains and found that media carrying CAS dye showed an orange zone by $\mathrm{C} 3 \mathrm{~S} 3 \mathrm{E}$, which is of $15 \mathrm{~mm}$ size, followed by other strains like C3S3D (11 mm), C3S3G (10 mm), Pa2S2E (4 mm), C3S3P (4 mm) and Pa2S2C (2 mm) whereas C3S3F, Pa3S3C, and H3S3A did not show any halo zone hence no siderophore production. The rhizobacterial isolates' antifungal potential was analyzed on PDA plates against Rosellinia sp. and Fusarium sp. (Table 1). In the control experiment (without inoculation of isolated strains), fungus showed normal growth, whereas bacteria's application restricted the growth of fungus. Maximum zone of inhibition against Rosellinia sp. was shown by Pa3S3C (75 \%) followed by Pa2S2C (67.50\%), Pa2S2E (62.90\%), C3S3F (58.33\%), C3S3P (58.28\%), C3S3E (55.45\%) and H3S3A (55.45\%), whereas C3S3G and C3S3D were unable to restrict the fungal growth (Table 1). In the case of biocontrol activity against Fusarium sp., the maximum zone of inhibition was shown by C3S3G (52.06\%) followed by C3S3E (51.66\%) and C3S3D (48.33\%). Strains like C3S3F, C3S3P, Pa3S3C, Pa2S2C, Pa2S2E, and H3S3A did not show any inhibition toward Fusarium sp. Only the C3S3E bacterial strain showed antifungal activity against both the fungi (Table 1). The phylogenetic analysis showed that rhizospheric bacterial strains harboring the PGP traits belonged to the genus Klebsiella, Enterobacter, Burkholderia, and Pantoea (Table 1).

All drought tolerant isolates were screened for ACC deaminase activity in which ACC was used as a sole nitrogen source. Out of these 9 isolates, we found that 4 isolates (Pa3S3C, Pa2S2C, Pa2S2E, and H3S3A) grew on DF minimal salts medium, indicating their ACC deaminase activity (Table 1).

The bacterial isolates that showed ACC deaminase activity were further assessed for EPS production under water-stressed (20\% PEG) and non-stressed conditions. Strain Pa2S2E

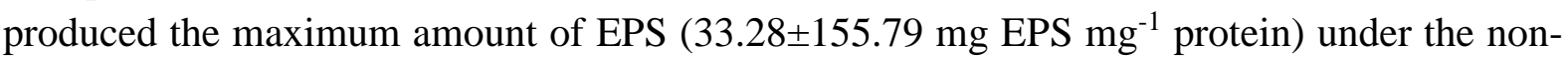
stressed condition, followed by isolate H3S3A (10.72 $\pm 13.59 \mathrm{mg}^{\mathrm{EPS}} \mathrm{mg}^{-1}$ protein), Pa2S2C (7.49 $\pm 17.99 \mathrm{mg}$ EPS mg$^{-1}$ protein), and Pa3S3C (6.99 $\pm 22.22 \mathrm{mg} \mathrm{EPS} \mathrm{mg}^{-1}$ protein). Under the 
drought stress condition, isolate Pa2S2E was the best producer of EPS $(17.16 \pm 11.37 \mathrm{mg} / \mathrm{mg}$

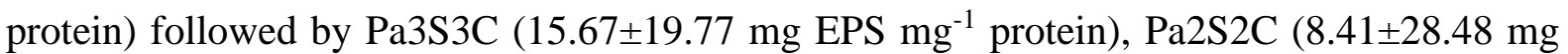
EPS $\mathrm{mg}^{-1}$ protein), and H3S3A (8.40 $\pm 22.83 \mathrm{mg} \mathrm{EPS} \mathrm{mg}^{-1}$ protein) (Table 1).

\subsection{Discussion.}

In the future, there is a great challenge to maintain agricultural productivity due to many factors. One of the critical factors is the availability of water. There could be many interventions to resolve the issue of the low-availability of irrigation water. In the present study, we focused on the microbes of an S. acmella, which can thrive under water stress, isolate strains that could help it do so, and help it grow either directly (biofertilizer activity) or indirectly (biocontrol activity). Microbes inside the roots or in the rhizospheric region of plants have been earlier studied, and the researchers found that the use of PGPR enhanced the growth of plants and reduced the effects of drought stress [32, 11-13, 33].

In this study, 53 phosphate solubilizing bacteria were isolated from the rhizosphere of S. acmella Murr. All the isolates were further screened for drought tolerance by analyzing their capability to thrive in the presence of polyethylene glycol 6,000 (PEG 6,000), which is supplemented in their growth media. Out of $53 \mathrm{PSB}$, nine strains were drought tolerant. Analysis of the strains' $16 \mathrm{~S}$ rDNA sequences revealed that the isolates belonged to four different genera: Klebsiella, Enterobacter, Burkholderia, and Pantoea. Previously, all these genera have been reported to confer biocontrol and biofertilizer properties [34-37]. Some of the strains of genus Burkholderia and Pantoea were also described as efficient phosphate solubilizers [38. 39, 32].

The Enterobacter sp. Pa3S3C isolated in our study exhibited higher drought tolerance (50\% PEG) as compared with previously reported Enterobacter hormaechei (-0.30 MPa) bacterial strain isolated from the plant Setaria italica L. [5]. Previously, reported droughtresistant Bacillus spp. that exhibited many PGP properties under drought stress, and it improved the overall growth of maize plant under drought stress of $-0.73 \mathrm{MPa}, 25 \%$ PEG [40]. Three bacterial strains, Pseudomonas putida, Pseudomonas strain GAP-P45, and Bacillus megaterium, were isolated from drought soil and were able to encourage plant growth under drought conditions [41, 42, 12].

Under a drought-stress environment, inoculation of PGPR is the most effective method to increase productivity. PGPR produce phytohormones, which ultimately enhance plant growth. Production of IAA, an active auxin, by several microorganisms, including PGPR through L-tryptophan metabolic pathway, help plant grow [41, 43, 44]. Under osmotic stress conditions, the production of IAA by PGPR was considered as a suitable marker for its effectiveness to overcome the drought stress [45]. In our study maximum, IAA production was seen in C3S3P, i.e., Klebsiella sp. IAA production was also seen in other PSB like Klebsiella SN 1.1 and Achromobacter xylosoxidans and [46]. Besides producing phytohormones and solubilization of phosphate, we found that strains isolated in our study were also able to overcome the impact of pathogenic fungi. These bacterial isolates decreased the normal growth of Fusarium sp. and Rosellinia sp.

To gain further insight into the impact of bacteria on decreasing the water deficiency stress, we inoculated the wheat seedlings with bacteria and gave the drought stress to seedlings. Impressively, we found that seedlings treated with bacteria showed an increase in growth parameters, i.e., shoot and root length compared to the seedlings treated with PEG only. We found that the seedling treated with Pantoea sp. showed a 1.28 fold increase in shoot length. 
Treatment with Burkholderia anthina increased 2.8 fold increase in root length. Similar studies were done to analyze the impact of bacteria on the plant's growth. It was reported that Burkholderia phytofirmans strain PsJN and Enterobacter sp. strain FD improved the overall growth of the plant in drought stress [47-53]. Similarly, under drought stress, an increase in plant growth due to PGPR treatment has also been reported in other crops, including Helianthus annuus L., Triticum aestivum, Vigna radiata L., Sorghum bicolor [52-55]. Plant growthpromoting bacteria has also been reported to produce ACC deaminase, which breaks ACC to ammonia and $\alpha$-ketobutyrate [56], thus encouraging root elongation and plant growth hydrolyzing ACC from germinating seeds and enhancing the active rhizosphere zone. [57] reported that ACC-deaminase produces rhizobacteria to alleviate water-stress impacts in wheat (Triticum aestivum L.) plants.

In the present study, seven isolates exhibited growth on DF salts minimal medium with ACC as a sole nitrogen source. ACC deaminase-producing bacteria are known to protect plants from various biotic (bacterial and fungal pathogens) and abiotic stresses (drought, flooding, salts, heavy metals) $[56,58]$. Therefore, bacteria producing ACC deaminase are important components of agriculture in stressed environments. Production of ammonia by bacteria is also an important trait as plants use ammonia as a source of nitrogen for their growth [59].

Plants treated with EPS-producing bacterial strains display increased resistance to water stress. The addition of EPS-producing microorganisms in the drought-stressed soils can alleviate stress in the crop plants. The EPS production of isolates was higher under stress than under no stress conditions. It increased by increasing stress level, indicating that EPS production in bacteria occurs as a response to the stress [12]. In previous studies, droughttolerant Pseudomonas sp. were also reported to produce a higher level of EPS under stressed conditions than under non-stressed ones, indicating that EPS production in bacteria occurs as a stress response $[9,5]$.

Since the strains isolated in the present study were found from a medicinal plant from the Himalayan region, these strains could help improve the growth of local crops like wheat, maize, peas, and tomato under drought conditions.

\section{Conclusions}

Since the drought conditions in the future could hit our agriculture practices to a greater extent, the strategy to utilize the symbiotic bacteria to mitigate the impact of drought would be very useful. These bacterial strains will not only improve the growth of plants but could also help in decreasing the effects of phytopathogens. This study has isolated drought-tolerant bacteria from the rhizosphere of S. acmella Murr. from the Shivah hills region of Himachal Pradesh. These drought-tolerant strains were isolated for the first time from this region, which could tolerate the drought stress up to 50\% PEG, which is higher than the stress level reported in the literature earlier (up to PEG 40\%). The improvement in growth towards the droughtstressed seedlings by these bacteria showed a promising utilization of these strains to decrease the impact of drought stress.

\section{Funding}

The Department of Science and Technology supports this research through INSPIRE Fellowship, Govt. of India. (DST/INSPIRE Fellowship/ 2015/IF150370) and Ministry of Environment, Forest and Climate Change, Govt. of India (NMHS/SG-2016/019). 


\section{Acknowledgments}

Menaka Thakur is supported by the Department of Science and Technology through INSPIRE Fellowship, Govt. of India. (DST/INSPIRE Fellowship/ 2015/IF150370). Divya Mittal is supported by the Ministry of Environment, Forest and Climate Change, Govt. of India (NMHS/SG-2016/019).

\section{Conflicts of Interest}

The authors declare that they have no conflict of interest in the publication.

\section{References}

1. Vinocur, B.; Altman, A. Recent advances in engineering plant tolerance to abiotic stress: achievements and limitations. Curr. Opin. Biotechnol. 2005, 16, 123-132, https://doi.org/10.1016/j.copbio.2005.02.001.

2. Gatehouse, A.M.R.; Ferry, N.; Edwards, M.G.; Bell, H.A. Insect-resistant biotech crops and their impacts on beneficial arthropods. Philosophical Transactions of the Royal Society B: Biological Sciences 2011, 366, 1438-1452, https://doi.org/10.1098/rstb.2010.0330.

3. Alexandratos, N.; Bruinsma, J. World agriculture towards 2030/2050: the 2012 revision. 2012, https://doi.org/10.22004/ag.econ.288998.

4. Farooq, M.; Wahid, A.; Kobayashi, N.; Fujita, D.; Basra, S.M.A. Plant Drought Stress: Effects, Mechanisms and Management. In Sustainable Agriculture, Lichtfouse, E., Navarrete, M., Debaeke, P., Véronique, S., Alberola, C., Eds. Springer Netherlands: Dordrecht, 2009, https://doi.org/10.1007/978-90-481-2666-8_12.

5. Niu, X.; Song, L.; Xiao, Y.; Ge, W. Drought-Tolerant Plant Growth-Promoting Rhizobacteria Associated with Foxtail Millet in a Semi-arid Agroecosystem and Their Potential in Alleviating Drought Stress. Front. Microbiol. 2018, 8, 2580, https://doi.org/10.3389/fmicb.2017.02580.

6. Cassán, F.; Maiale, S.; Masciarelli, O.; Vidal, A.; Luna, V.; Ruiz, O. Cadaverine production by Azospirillum brasilense and its possible role in plant growth promotion and osmotic stress mitigation. Eur. J. Soil Biol. 2009, 45, 12-19, https://doi.org/10.1016/j.ejsobi.2008.08.003.

7. Glick, B.R.; Cheng, Z.; Czarny, J.; Duan, J. Promotion of plant growth by ACC deaminase-producing soil bacteria. In New Perspectives and Approaches in Plant Growth-Promoting Rhizobacteria Research, Bakker, P.A.H.M., Raaijmakers, J.M., Bloemberg, G., Höfte, M., Lemanceau, P., Cooke, B.M., Eds. Springer Netherlands: Dordrecht, 2007,329-339, https://doi.org/10.1007/978-1-4020-6776-1_8.

8. Getahun, A.; Muleta, D.; Assefa, F.; Kiros, S. Plant Growth-Promoting Rhizobacteria Isolated from Degraded Habitat Enhance Drought Tolerance of Acacia $(<\mathrm{i}>$ Acacia abyssinica $</ \mathrm{i}>$ Hochst. ex Benth.) Seedlings. Int. J. Microbiol. 2020, 2020, 8897998, https://doi.org/10.1155/2020/8897998.

9. Ali, S.Z.; Sandhya, V.; Venkateswar Rao, L. Isolation and characterization of drought-tolerant ACC deaminase and exopolysaccharide-producing fluorescent Pseudomonas sp. Ann. Microbiol. 2014, 64, 493502, https://doi.org/10.1007/s13213-013-0680-3.

10. Patel Priyanka, J.; Trivedi Goral, R.; Shah Rupal, K.; Saraf, M. Rhizospheric Microflora: A Natural Alleviator of Drought Stress in Agricultural Crops. In Plant Growth Promoting Rhizobacteria for Sustainable Stress Management : Volume 1: Rhizobacteria in Abiotic Stress Management, Sayyed, R.Z., Arora, N.K., Reddy, M.S., Eds. Springer Singapore: Singapore, 2019; 103-115, https://doi.org/10.1007/978-981-13-6536-2_6.

11. Bashan, Y.; Holguin, G.; de-Bashan, L.E. Azospirillum-plant relationships: physiological, molecular, agricultural, and environmental advances (1997-2003). Can. J. Microbiol. 2004, 50, 521-577, https://doi.org/10.1139/w04-035.

12. Jochum, M.D.; McWilliams, K.L.; Borrego, E.J.; Kolomiets, M.V.; Niu, G.; Pierson, E.A.; Jo, Y.-K. Bioprospecting Plant Growth-Promoting Rhizobacteria That Mitigate Drought Stress in Grasses. Front. Microbiol. 2019, 10, 2106, https://doi.org/10.3389/fmicb.2019.02106.

13. Sandhya, V.; Sk. Z, A.; Grover, M.; Reddy, G.; Venkateswarlu, B. Alleviation of drought stress effects in sunflower seedlings by the exopolysaccharides producing Pseudomonas putida strain GAP-P45. Biol. Fertility Soils 2009, 46, 17-26, https://doi.org/10.1007/s00374-009-0401-z.

14. Zahir, Z.A.; Munir, A.; Asghar, H.N.; Shaharoona, B.; Arshad, M. Effectiveness of rhizobacteria containing ACC deaminase for growth promotion of peas (Pisum sativum) under drought conditions. J. Microbiol. Biotechnol. 2008, 18, 958-963. 
15. Tiwari, K.L.; Jadhav, S.K.; Joshi, V. An updated review on medicinal herb genus Spilanthes. Zhong xi yi jie he xue bao= Journal of Chinese Integrative Medicine 2011, 9, 1170-1178, https://doi.org/10.3736/jcim20111103.

16. Chauhan, N.S. Medicinal and aromatic plants of Himachal Pradesh; Indus publishing: 2006, 215-218.

17. Thakur, A.; Singh, K. Medicinal Plants of the Shimla Hills, Himachal Pradesh: A Survey. 2014, 118, 118127.

18. Purushothaman, Y.; Gunaseelan, S.; Vijayakumar, S.D. Spilanthes acmella and its medicinal uses-A review. Asian Journal of Pharmaceutical and Clinical Research 2018, 11, 45-49, http://dx.doi.org/10.22159/ajpcr.2018.v11i6.24697.

19. Zhang, M.; Yang, L.; Hao, R.; Bai, X.; Wang, Y.; Yu, X. Drought-tolerant plant growth-promoting rhizobacteria isolated from jujube (Ziziphus jujuba) and their potential to enhance drought tolerance. Plant Soil 2020, 452, 423-440, https://doi.org/10.1007/s11104-020-04582-5.

20. Chandra, P.; Wunnava, A.; Verma, P.; Chandra, A.; Sharma, R.K. Strategies to mitigate the adverse effect of drought stress on crop plants-influences of soil bacteria: A review. Pedosphere 2021, 31, 496-509, https://doi.org/10.1016/S1002-0160(20)60092-3.

21. Joshi, B.; Chaudhary, A.; Singh, H.; Kumar, P.A. Prospective evaluation of individual and consortia plant growth promoting rhizobacteria for drought stress amelioration in rice (Oryza sativa L.). Plant Soil 2020, 457, 225-240, https://doi.org/10.1007/s11104-020-04730-X.

22. Sharma, G.; Gupta, V.; Sharma, S.; Shrivastava, B.; Bairva, R. Toothache plant Spilanthes acmella Murr.: a review. J Natura Conscientia 2010, 1, 135-142.

23. Mittal, D.; Shukla, R.; Verma, S.; Sagar, A.; Verma, K.S.; Pandey, A.; Negi, Y.S.; Saini, R.V.; Saini, A.K. Fire in pine grown regions of Himalayas depletes cultivable plant growth promoting beneficial microbes in the soil. Applied Soil Ecology 2019, 139, 117-124, https://doi.org/10.1016/j.apsoil.2019.03.020.

24. Govindaraj, M.; Shanmugasundaram, P.; Sumathi, P.; Muthiah, A.R. Simple, rapid and cost effective screening method for drought resistant breeding in pearl millet. Electronic journal of plant breeding 2010, 1 , 590-599.

25. Sudheesh, K.; Shivanand, H.; Shoba, N. Standardization of optimal concentration of PEG 6000 for induction of drought and screening of coriander (Coriandrum sativum L.) genotypes. Asian Journal of Horticulture 2014, 9, 100-105.

26. Sibero, M.T.; Bachtiarini, T.U.; Trianto, A.; Lupita, A.H.; Sari, D.P.; Igarashi, Y.; Harunari, E.; Sharma, A.R.; Radjasa, O.K.; Sabdono, A. Characterization of a yellow pigmented coral-associated bacterium exhibiting anti-Bacterial Activity Against Multidrug Resistant (MDR) Organism. The Egyptian Journal of Aquatic Research 2019, 45, 81-87, https://doi.org/10.1016/j.ejar.2018.11.007.

27. Gupta, H.; Saini, R.V.; Pagadala, V.; Kumar, N.; Sharma, D.K.; Saini, A.K. Analysis of plant growth promoting potential of endophytes isolated from Echinacea purpurea and Lonicera japonica. Journal of soil science and plant nutrition 2016, 16, 558-577, http://dx.doi.org/10.4067/S0718-95162016005000025.

28. Kang, S.-M.; Shahzad, R.; Bilal, S.; Khan, A.L.; Park, Y.-G.; Lee, K.-E.; Asaf, S.; Khan, M.A.; Lee, I.-J. Indole-3-acetic-acid and ACC deaminase producing Leclercia adecarboxylata MO1 improves Solanum lycopersicum L. growth and salinity stress tolerance by endogenous secondary metabolites regulation. BMC Microbiol. 2019, 19, 80, https://doi.org/10.1186/s12866-019-1450-6.

29. Myo, E.M.; Ge, B.; Ma, J.; Cui, H.; Liu, B.; Shi, L.; Jiang, M.; Zhang, K. Indole-3-acetic acid production by Streptomyces fradiae NKZ-259 and its formulation to enhance plant growth. BMC Microbiol. 2019, 19, 155, https://doi.org/10.1186/s12866-019-1528-1.

30. Slama, H.B.; Cherif-Silini, H.; Chenari Bouket, A.; Qader, M.; Silini, A.; Yahiaoui, B.; Alenezi, F.N.; Luptakova, L.; Triki, M.A.; Vallat, A.; Oszako, T.; Rateb, M.E.; Belbahri, L. Screening for Fusarium Antagonistic Bacteria From Contrasting Niches Designated the Endophyte Bacillus halotolerans as Plant Warden Against Fusarium. Front. Microbiol. 2019, 9, 3236, https://doi.org/10.3389/fmicb.2018.03236.

31. Narayan, O.P.; Verma, N.; Singh, A.K.; Oelmüller, R.; Kumar, M.; Prasad, D.; Kapoor, R.; Dua, M.; Johri, A.K. Antioxidant enzymes in chickpea colonized by Piriformospora indica participate in defense against the pathogen Botrytis cinerea. Sci. Rep. 2017, 7, 13553, https://doi.org/10.1038/s41598-017-12944-w.

32. Vyas, P.; Kaur, R. Culturable Stress-Tolerant Plant Growth-Promoting Bacterial Endophytes Associated with Adhatoda vasica. Journal of Soil Science and Plant Nutrition 2019, 19, 290-298, https://doi.org/10.1007/s42729-019-00028-9.

33. Patel Priyanka, J.; Trivedi Goral, R.; Shah Rupal, K.; Saraf, M. Rhizospheric Microflora: A Natural Alleviator of Drought Stress in Agricultural Crops. In Plant Growth Promoting Rhizobacteria for Sustainable Stress 
Management : Volume 1: Rhizobacteria in Abiotic Stress Management, Sayyed, R.Z., Arora, N.K., Reddy, M.S., Eds. Springer Singapore: Singapore, 2019; 103-115, https://doi.org/10.1007/978-981-13-6536-2_6.

34. Usha, D.; Khatri, I.; Lalit, K.; Devender, S.; Aditi, G.; Navinder, K.; Gárriz, A.; Subramanian, S.; Sharma, D.; Adesh, S.K. Genomic and functional characterization of a novel Burkholderia sp. strain AU4i from pea rhizosphere conferring plant growth promoting activities. 2015.

35. Nguyen, H.T.; Deaker, R.; Kennedy, I.R.; Roughley, R.J. The positive yield response of field-grown rice to inoculation with a multi-strain biofertiliser in the Hanoi area, Vietnam. Symbiosis 2003.

36. Shaharoona, B.; Jamro, G.M.; Zahir, Z.A.; Arshad, M.; Memon, K.S. Effectiveness of various Pseudomonas spp. and Burkholderia caryophylli containing ACC-deaminase for improving growth and yield of wheat (Triticum aestivum L.). J. Microbiol. Biotechnol. 2007, 17, 1300-1307.

37. Shoebitz, M.; Ribaudo, C.M.; Pardo, M.A.; Cantore, M.L.; Ciampi, L.; Curá, J.A. Plant growth promoting properties of a strain of Enterobacter ludwigii isolated from Lolium perenne rhizosphere. Soil Biol. Biochem. 2009, 41, 1768-1774, https://doi.org/10.1016/j.soilbio.2007.12.031.

38. Khatri, I.; Kaur, S.; Devi, U.; Kumar, N.; Sharma, D.; Subramanian, S.; Saini, A.K. Draft Genome Sequence of Plant Growth-Promoting Rhizobacterium \&lt;em\&gt;Pantoea\&lt;/em\&gt; sp. Strain AS-PWVM4. Genome Announcements 2013, 1, e00947-00913, https://doi.org/10.1128/genomeA.00947-13.

39. Silini-Cherif, H.; Silini, A.; Ghoul, M.; Yadav, S. Isolation and characterization of plant growth promoting traits of a rhizobacteria: Pantoea agglomerans lma2. Pakistan journal of biological sciences: PJBS 2012, 15, 267-276, https://doi.org/10.3923/pjbs.2012.267.276.

40. Walpola, B.; Yoon, M.-H. Isolation and characterization of phosphate solubilizing bacteria and their coinoculation efficiency on tomato plant growth and phosphorous uptake. Afr. J. Microbiol. Res. 2013, 7, 266275, https://doi.org/10.5897/AJMR12.2282.

41. Vardharajula, S.; Zulfikar Ali, S.; Grover, M.; Reddy, G.; Bandi, V. Drought-tolerant plant growth promoting Bacillus spp.: effect on growth, osmolytes, and antioxidant status of maize under drought stress. Journal of Plant Interactions 2011, 6, 1-14, https://doi.org/10.1080/17429145.2010.535178.

42. Kour, D.; Rana, K.L.; Sheikh, I.; Kumar, V.; Yadav, A.N.; Dhaliwal, H.S.; Saxena, A.K. Alleviation of Drought Stress and Plant Growth Promotion by Pseudomonas libanensis EU-LWNA-33, a Drought-Adaptive Phosphorus-Solubilizing Bacterium. Proceedings of the National Academy of Sciences, India Section B: Biological Sciences 2020, 90, 785-795, https://doi.org/10.1007/s40011-019-01151-4.

43. Marulanda, A.; Barea, J.-M.; Azcón, R. Stimulation of Plant Growth and Drought Tolerance by Native Microorganisms (AM Fungi and Bacteria) from Dry Environments: Mechanisms Related to Bacterial Effectiveness. J. Plant Growth Regul. 2009, 28, 115-124, https://doi.org/10.1007/s00344-009-9079-6.

44. Ciccillo, F.; Fiore, A.; Bevivino, A.; Dalmastri, C.; Tabacchioni, S.; Chiarini, L. Effects of two different application methods of Burkholderia ambifaria MCI 7 on plant growth and rhizospheric bacterial diversity. Environ. Microbiol. 2002, 4, 238-245, https://doi.org/10.1046/j.1462-2920.2002.00291.x.

45. Trân Van, V.; Berge, O.; Ngô Kê, S.; Balandreau, J.; Heulin, T. Repeated beneficial effects of rice inoculation with a strain of Burkholderia vietnamiensison early and late yield components in low fertility sulphate acid soils of Vietnam. Plant Soil 2000, 218, 273-284, https://doi.org/10.1023/A:1014986916913.

46. Boiero, L.; Perrig, D.; Masciarelli, O.; Penna, C.; Cassán, F.; Luna, V. Phytohormone production by three strains of Bradyrhizobium japonicum and possible physiological and technological implications. Appl. Microbiol. Biotechnol. 2007, 74, 874-880, https://doi.org/10.1007/s00253-006-0731-9.

47. Jha, P.; Kumar, A. Characterization of Novel Plant Growth Promoting Endophytic Bacterium Achromobacter xylosoxidans from Wheat Plant. Microb. Ecol. 2009, 58, 179-188, https://doi.org/10.1007/s00248-009-94850 .

48. Yasmin, H.; Bano, A.; Ullah, S. Screening of PGPR isolates from semi-arid region and their implication to alleviate drought stress. Pakistan Journal of Botany 2013, 45, 51-58.

49. Naseem, H.; Bano, A. Role of plant growth-promoting rhizobacteria and their exopolysaccharide in drought tolerance of maize. Journal of Plant Interactions 2014, 9, 689-701, https://doi.org/10.1080/17429145.2014.902125.

50. Naveed, M.; Mitter, B.; Reichenauer, T.G.; Wieczorek, K.; Sessitsch, A. Increased drought stress resilience of maize through endophytic colonization by Burkholderia phytofirmans PsJN and Enterobacter sp. FD17. Environ. Exp. Bot. 2014, 97, 30-39, https://doi.org/10.1016/j.envexpbot.2013.09.014.

51. Ngumbi, E.N. Mechanisms of olfaction in parasitic wasps: analytical and behavioral studies of response of a specialist (Microplitis croceipes) and a generalist (Cotesia marginiventris) parasitoid to host-related odor. 2011. 
52. Sandhya, V.; Ali, S.Z.; Grover, M.; Reddy, G.; Venkateswarlu, B. Effect of plant growth promoting Pseudomonas spp. on compatible solutes, antioxidant status and plant growth of maize under drought stress. Plant Growth Regulation 2010, 62, 21-30, https://doi.org/10.1007/s10725-010-9479-4.

53. Haque, M.M.; Mosharaf, M.K.; Khatun, M.; Haque, M.A.; Biswas, M.S.; Islam, M.S.; Islam, M.M.; Shozib, H.B.; Miah, M.M.U.; Molla, A.H.; Siddiquee, M.A. Biofilm Producing Rhizobacteria With Multiple Plant Growth-Promoting Traits Promote Growth of Tomato Under Water-Deficit Stress. Front. Microbiol. 2020, $11,2954$.

54. Grover, M.; Madhubala, R.; Ali, S.Z.; Yadav, S.K.; Venkateswarlu, B. Influence of Bacillus spp. strains on seedling growth and physiological parameters of sorghum under moisture stress conditions. J. Basic Microbiol. 2014, 54, 951-961, https://doi.org/10.1002/jobm.201300250.

55. Chiappero, J.; Cappellari, L.d.R.; Sosa Alderete, L.G.; Palermo, T.B.; Banchio, E. Plant growth promoting rhizobacteria improve the antioxidant status in Mentha piperita grown under drought stress leading to an enhancement of plant growth and total phenolic content. Industrial Crops and Products 2019, 139, 111553, https://doi.org/10.1016/j.indcrop.2019.111553.

56. Saravanakumar, D.; Kavino, M.; Raguchander, T.; Subbian, P.; Samiyappan, R. Plant growth promoting bacteria enhance water stress resistance in green gram plants. Acta Physiologiae Plantarum 2011, 33, 203209, https://doi.org/10.1007/s11738-010-0539-1.

57. Chandra, D.; Srivastava, R.; Gupta, V.V.S.R.; Franco, C.M.M.; Sharma, A.K. Evaluation of ACC-deaminaseproducing rhizobacteria to alleviate water-stress impacts in wheat (Triticum aestivum L.) plants. Can. J. Microbiol. 2019, 65, 387-403, https://doi.org/10.1139/cjm-2018-0636.

58. Glick, B.R. Bacteria with ACC deaminase can promote plant growth and help to feed the world. Microbiol. Res. 2014, 169, 30-39, https://doi.org/10.1016/j.micres.2013.09.009.

59. Saikia, J.; Sarma, R.K.; Dhandia, R.; Yadav, A.; Bharali, R.; Gupta, V.K.; Saikia, R. Alleviation of drought stress in pulse crops with ACC deaminase producing rhizobacteria isolated from acidic soil of Northeast India. Sci. Rep. 2018, 8, 3560, https://doi.org/10.1038/s41598-018-21921-w. 